Alignment: Journal of Administration and Educational Management

Volume 1, Nomor 2, Desember 2018

e-ISSN : 2598-5159

p-ISSN : 2598-0742

DOI : https://doi.org/10.31539/alignment.v1i2.436

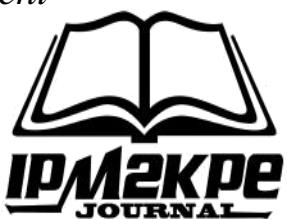

\title{
STRATEGI PENINGKATAN EKSISTENSI MADRASAH IBTIDAIYAH (MI) DI KABUPATEN REJANG LEBONG
}

\author{
Beni Azwar', ${ }^{1}$ aryanto ${ }^{2}$, Rahmad Hidayat ${ }^{3}$, Masudi $^{4}$ \\ Institut Agama Islam Negeri Curup ${ }^{1,2,3,4}$ \\ beni2018@gmail.com
}

\begin{abstract}
ABSTRAK
Tujuan penelitian ini adalah untuk mengkaji strategi peningkatan eksistensi Madrasah Ibtidaiyah (MI) di Kabupaten Rejang Lebong. Penelitian ini menggunakan pendekatan sosiologisuntuk memahami makna peristiwa serta interaksi pada orangorang dalam situasi tertentu. Hasil penelitian, Madrasah Ibtidaiyah (MI) ternyata cukup eksis membantu perkembangan pendidikan, hal ini bisa dilihat dari program kerja, kemudian siswanya cukup kompetitif, prestasi siswa sampai ke tingkat Regional maupun Nasional. Simpulan, strategi yang di gunakan dalam meningkatkan eksistensi Madrasah Ibtidaiyah, yakni menggunakan strategi POAC yaitu planning organizing, actuating, controling dalam meningkatkan eksistensi Madrasah Ibtidaiyah (MI) di Kabupaten Rejang Lebong
\end{abstract}

Kata Kunci: Strategi, Eksistensi, Madrasah Ibtidaiyah

\section{ABSTRACT}

The study aims at discussing the strategy to improve the existence of Madrasah Ibtidaiyah (MI) in Rejang Lebong regency. The research used sociological approach to comprehend the meaning of events and interaction of people in certain circumstances. The results were: Madrasah Ibtidaiyah (MI) was quite exist in assisting the education advance. It can be noticed by the work programs. The students were competitive and their achievements reached regional and national level. In conclusion, the strategy used to improve the existence of Madrasah Ibtidaiyah, such as using POAC strategy (planning organizing, actuating), as well as controling improved the existence of Madrasah Ibtidaiyah (MI) in Rejang Lebong regency.

Keywords : strategy, existence, Madrasah Ibtidaiyah 


\section{PENDAHULUAN}

Dalam masyarakat akhir-akhir ini terjadi adanya pergeseran pandangan terhadap pendidikan seiring dengan tuntutan masyarakat (social demand) yang berkembang dalam skala yang lebih makro. Pada saat ini, masyarakat melihat pendidikan tidak lagi dipandang hanya sebagai bentuk pemenuhan kebutuhan terhadap perolehan pengetahuan dan ketrampilan dalam konteks waktu sekarang. Lebih dari itu, pendidikan dipandang sebagai bentuk investasi, baik modal maupun manusia (human and capital investmen) untuk membantu meningkatkan keterampilan dan pengetahuan sekaligus mempunyai kemampuan produktif di masa depan yang diukur dari tingkat penghasilan yang diperolehnya (Shaleh, 2006).

Image masyarakat terhadap Madrasah sering diidentikkan dengan lembaga pendidikan second class, tidak maju, kumuh, dan citra negatif lainya masih sering menempel di madrasah. Rendahnya animo masyarakat menengah atas (upper midle class) untuk menyekolahkan anaknya ke madrasah (Shaleh, 2006). Tugas yang diemban madrasah di era globalisasi ini semakin berat. Sebagai lembaga pendidikan yang berbasis nilai-nilai keagamaan, madrasah tidak hanya dituntut untuk melakukan transfer of knowledge, tetapi juga transfer of Islamic values. Padahal, lembaga madrasah sendiri saat ini masih bergelut dengan sekian permasalahan yang tidak kunjung selesai (intellectual deadlock).

Secara historis, pada tahap-tahap awal perjalanan madrasah tidaklah begitu mulus, kendatipun didirikan dengan nama madrasah, semula yang dikehendaki ialah suatu lembaga pendidikan dengan sistem klasikal, yang di dalamnya anak didik mendapatkan ilmu pengetahuan agama dan pengetahuan umum secara berimbang. Tetapi pada prakteknya, hanya dicerminkan oleh sistem kalsikalnya saja, sementara kurikulum yang diajarkan tetap semata-mata bidang studi agama. Karena itu banyak madrasah pada tahap awal ini tidak bedanya dengan pesantren tradisional yang sudah lama berjalan.

Dari kenyataan-kenyataan tersebut, maka oleh Dapartemen Agama diadakanlah upaya-upaya untuk peningkatan kualitas madrasah, yang salah satu aspeknya adalah kurikulum. Untuk masalah kurikulum ini, dalam perkembanganya telah telah beberapa kali diadakan perubahan, dari yang muatanya lebih banyak pengetahuan agama ketimbang pengetahuan umum

KH. M. Sahal Mahfudh, yang akrab dipanggil Mbah Sahal, menyebutkan bahwa sedikitnya ada tiga masalah penting yang saat ini dihadapi madrasah. Pertama, masalah identitas diri madrasah dalam hubungannya dengan karakteristik dan independensinya terhadap lembaga-lembaga lain yang ada di masyarakat. Kedua, masalah jenis pendidikan yang dipilih sebagai alternatif dasar yang dikelola untuk menciptakan suatu sistem pendidikan yang masih memiliki titik 
tekan keagamaan, tetapi pengetahuan umum tetap diberi porsi yang cukup sebagai basis mengantisipasi perkembangan masyarakat. Ketiga, masalah sumber daya dan pemanfaatannya bagi pengembangan madrasah sendiri di masa mendatang.

Ada dua hal yang menarik dari pandangan M. Sahal Mahfudh di atas, yaitu mengenai keseimbangan kurikulum masyarakat dan responnya terhadap dinamika zaman. Tokoh NU asal Pati ini sebetulnya hendak menyatakan bahwa saat ini kurikulum madrasah masih kental dengan nuansa akhirat, sekalipun sudah ada pelajaran-pelajaran umum di dalamnya. Pembelajaran madrasah saat ini masih lebih memfokuskan pada masalah-masalah keagamaan, sehingga unsur pengembangan IPTEK (ilmu pengetahuan dan teknologi) cenderung kurang mendapat porsi yang seimbang.

Hal ini sekaligus berdampak pada kurangnya kepekaan madrasah terhadap dinamika zaman dan kebutuhan masyarakat. Sistem pendidikan madrasah yang ada saat ini tidak jauh berbeda dengan apa yang diterapkannya dalam satu dasawarsa sebelumnya. Padahal, perubahan zaman berikut budayanya terus berkembang silih berganti, dan kini masyarakat dunia tengah berada di sebuah zaman yang dikenal dengan sebutan globalisasi.

Karenanya, kita membutuhkan madrasah yang peka zaman, bukan madrasah yang ketinggalan zaman. Artinya, madrasah di tuntut untuk menjadikan dirinya sebagai pelayan pendidikan yang memuaskan umat Muslim. Hal ini tentunya dilakukan dengan tanpa menghilangkan identitas dan ciri khas madrasah sebagai institusi pendidikan Islam yang bernuansa religius.

Justru di era globalisasi seperti sekarang ini, di mana masyarakat mulai kering dengan hal-hal yang berbau keagamaan, eksistensi madrasah sebagai lembaga bernuansa keagamaan mutlak dipertahankan. Hal ini tidak cukup apabila tidak diiringi dengan keseriusan pengembangan masyarakat sebagai bentuk respons dirinya atas perkembangan dan kebutuhan masyarakat global (Shaleh, 2006).

\section{METODE PENELITIAN}

Penelitian ini menggunakan pendekatan sosiologis. Karena terkait langsung dengan gejala-gejala yang muncul di sekitar lingkungan manusia terorganisir dalam satuan pendidikan formal yaitu Madrasah. Penelitian yang menggunakan pendekatan sosiologis berusaha untuk memahami makna peristiwa serta interaksi pada orangorang dalam situasi tertentu. Pendekatan ini menghendaki adanya sejumlah asumsi yang berlainan dengan cara yang digunakan untuk mendekati perilaku orang dengan maksud menemukan fakta.

Penelitian ini merupakan penelitian lapangan (field research), yakni penelitian yang pengumpulan datanya dilakukan di lapangan dengan lokasi Madrasah Ibtidaiyah 
di lingkungan Kbupaten Rejang Lebongyang tujuannya untuk mengadakan pengamatan sejauh mana eksistensi MADRASAH ibtidaiyah di kab. Rejang Lebong (Moleong, 2008). Jenis penelitian ini merupakan penelitian deskriptif kualitatif yaitu penelitian tentang data yang dikumpulkan dan dinyatakan dalam bentuk kata-kata dan gambar, kata-kata disusun dalam kalimat, misalnya kalimat hasil wawancara antara peneliti dan informan.

Sumber data dalam penelitian adalah subjek dari mana data dapat diperoleh (Arikunto, 2006). Sumber data utama menurut Lofland dalam penelitian kualitatif adalah kata-kata dan tindakan, sedangkan data tertulis, foto, statistic, dokumen adalah data tambahan (Moleong, 2008).

Adapun sumber data yang digunakan peneliti sebagai subyek penelitian adalah: Data Primer yaitu data pertama yang diperoleh dari pihak utama. Data primer dalam penelitian ini adalah hasil observasi dan wawancara proses pembiasaan kegiatan keagamaan. Data ini dijadikan sebagai data pertama yang diambil oleh peneliti, untuk memperoleh hasil yang masksimal.Berdasarkan fokus penelitian, maka yang menjadi sumber data dalam penelitian ini adalah (a) Kepala Madrasah Ibtidaiyah yang ada di wilayah Rejang Lebong Rejang Lebong, (b) Para guru Madrasah Ibtidaiyah yang ada di wilayah Kab. Rejang Lebong, (c) Pihak-pihak yang terkait yang mendukung terhadap peningkatan eksistensi Madrasah Ibtidaiyah di Kab. Rejang Lebong; Data Sekunder yaitu merupakan sumber data yang membantu memberikan keterangan atau data pelengkap sebagai pembanding. Dalam hal ini data sekunder diperoleh dari data dokumentasi.

Penelitian dilakukan selama kurang lebih 4 bulan yakni sejak bulan 14 Juni sampai 31 Oktober 2017. Adapun lokasi penelitian Madrasah Ibtidaiyah di Lingkungan Kab.Rejang Lebong. Dalam penelitian kualitatif, yang menjadi instrument atau alat penelitian adalah peneliti itu sendiri. Oleh karena itu peneliti sebagai instrument juga harus "divalidasi" seberapa jauh peneliti kualitatif siap melakukan penelitian yang selanjutnya terjun ke lapangan (Sugiyono, 2006). Peneliti kualitatif sebagai human instrument karena berfungsi menetapkan focus penelitian dan memilih informan sebagai sumber data.

Berdasarkan hal diatas maka dalam penelitian kualitatif, peneliti menjadi instrument penelitian yang paling utama. Karena sesuatu yang akan dicari dari objek penelitian belum begitu jelas baik itu dari segi masalahnya, prosedur penelitiannya, ataupun dari hasil yang diharapkan. Rancangan penelitian masih bersifat sementara dan akan berkembang setelah peneliti memasuki obyek penelitian. Oleh karena itu dalam penelitian kualitatif " the researcher is the key instrument" (Sugiyono, 2007). Jadi peneliti adalah instrument kunci dalam penelitian kualitatif. Untuk melengkapi 
metode dalam pengumpulan data, penulis menggunakan beberapa metode sebagai berikut: observasi, wawancara, dokumentasi

Analisis data merupakan salah satu rangkaian kegiatan penilaian yang amat penting dan menentukan. Melalui kegiatan analisis inilah, data atau informasi yang dikumpulkan menjadi lebih bermakna. Analisis data dapat dikelompokkan menjadi tiga tahap, yaitu tahap pengolahan data, tahap pengorganisasian data, dan tahap penemuan hasil (Ainin, 2007)

\section{HASIL DAN PEMBAHASAN}

Di lihat daei eksistensinya Madrasah Ibtidaiyah di wilayah Kabupaten Rejang lebong rata-rata sudah punya kontribusi yang yang tinggi, hal ini bisa di lihat dari hasil wawancara kepada para kepala Madrasah, di antaranya hasil wawancara dengan bapak Wawan Herianto, Kepala Madrasah MIN 1 Rejang Lebong yang terletak di Dusun curup beliau menyatakan:“...Berdasarkan pertanyaan bapak maka perlu saya sampaikan bahwa kami senantiasa berusaha untuk berperan aktif dalam mendukung eksistensi terhadap kepentingan pemerintah daerah khususnya rejang lebong, terobosan yang kami tempuh adalah keseriusan kami dalam memimpin madrasah di antaranya ikut menyukseskan MTQ, memgikut sertakan lomba-lomba yang di selenggarakan pemerintah Daerah Kab. Rejang Lebong, serta kegiatan-kegiatan lain yang bernuansa Islami.Kami juga berusaha untuk ikut aktif dalam kegiatan hari ulang tahun curup, kami senantiasa mengirimkan yuri lomba-lomba yang bernuansa Keislaman.

Demikian juga pada hasil wawancara dengan kepala Madrasah lainnya ,mereka menyatakan masing-masing kepala medrasah sudah punya program masing-masing dalam menciptakan karyanya dalam meningkatkan eksistensinya. Eksisteni tersebut bisa di lihat dari ikut mensukseskan program Pemerintah Daerah Kabupaten Rejang lebong dalam menciptakan masyarakat Rejang Lebog yang religius. Diantaranya ikut mensukseskan MTQ tingkat Kabupaten, mewakili lomba-lomba tingkat asional, karya bakti daerah,

Di lihat dari strategi Kepala Madrasah Ibtidaiyah (MI) dakam meningatkan eksistensinya di lingkungan Kabupaten Rejang Lebong, Menggunakan pendekatan Manajemen Berbasis Sekolah, yaitu dengan memadukan empat unsur penting. Adapun empat unsur penting dalam sebuah Manajenen yaitu : Planning (Perencanaan), Organizing (Pembagian tugas), Actuating (pergerakan), Controling (pengawasan/pengendalian), adapun pengertiannya: Planing (Perencanaan) adalah proses mendefinisikan tujuan organisasi, membuat strategi untuk mencapai tujuan itu dan mengembangkan rencana aktivitas kerja dalam sebuah organisasi. Perencanaan 
merupakan proses yang penting dari segala bentuk fungsi manajemen, karena tanpa adanya perencanaan semua fungsi-fungsi lainnya tidak akan dapat berjalan.

\section{Planning}

Dalam perencanaan strategi kepala madrasah berangkat dari Visi Misi Madrasah, haal ini bisa di lihat dari salah satu hasil wawancara , seperti halnya hasil wawancara dengan kepala MIN 04 Rejang Lebong di Kota Padang yaitu bapak Eko Susilo,. M.Pd beliau mengatakan“..... dalam meningkatkan eksistensi madrasah di kab.Rejang Lebong kami senantiasa menyusun program yang bisa mendukun terhadap eksistensi madrasah ibtidaiyah diantaranya: 1). Membentu ahlak anak yang berkarakter; 2) mewajibkan anak pandai membaca Alqur'an ; 3) mewajibkan anakanak hafal ayat-ayat pendek;4 ) Mewajibkan anak-anak melaksanakan sholat duha dan sholat zuhur selama berjamaah; 5) Setiap guru wajib membimbing anak asuh dalam bacaan hafal Alqur'an.

Demikian juga dalam peran aktif madrasah ibtidaiyah peneliti juga mengadakan wawancara ke Mis Muhammadiyah Talang Ulu .Curup Timur Rejang Lebong, Yang di pimpin oleh ibu Cicah Nurhidayah, S.Pd.I sebagai berikut:“ Peran aktif kami sebagai kepala Madrasah dalam mendukung eksistensi di rejang lebong kami selalu berusaha melaksanakan program-program Rejang Lebong yang religius, diantaranya lebih mengutamakan kegiatan yang bernuansa keagamaan, juga ikut berperan serta dalam kegiatan perlombaan-perlombaan yang di selenggarakan oleh pemerintah daerah Kab. Rejang Lebong, baik dalam bentuk MTQ, Pidacil. Demikian juga seperti yang di lakukan sekolah lain maka pada prinsipnya dalam perencanaan atau planning kepala madrasah senantiasa di sinergikan dengan kepentingan Daerah.

\section{Organizing}

Dalam Pembagian tugas para Kepala Madrasah senantiasa menyesuaikan dengan tingkat profesionalime guru masing-masing untuk menjaga kualitas tingkat efektif dan efisiensi kegiatan, seperti yang telah di sampaikan Hal ini juga di lakukan oleh Kepala MIS GUPPI N0.13 Tasik Malaya beliau menyatakan:“ Kepala MIS N0 13 Tasik malaya senatias fres dalam mengorganisasikan program-program dalam rangka meningatkan eksistensi nya di antaranya: 1) Setiap kegiatan di berikan kepada salah satu guru untuk menjadi kooardinator dan pelatih; 2) Setiap guru memiliki tanggung jawab terhadap kegiatan yang telah di berikan oleh kepala madrasah; 3) Khusus kegiatan ekstrakurikuler di berkan uang transport; 4) setiap siswa siswi yang berprestasi di berikan reword dari madrasah ibtidaiyah. Dari hasil wawancara di atas yang di ikuti wawancara MI yang lainnya, maka para kepala Madrasah senantiasa 
menunjuk guru sebagai koordinator atau penanggung jawab setiap kegiatan yang ada di madrasah.

\section{Actuating}

Dalam konsep tindakan dalam meningkatkan eksistensi Kepala Madrasah , senantiasa melaksanakan program yang telah di rencanakan secara maksimal, seperti di lihat dari salah satu hasil wawancara peneliti yang di laksanakan di MIS GUPPI No.12 Lubuk Kembang, pada dasarnya juga sama yaitu dalam tindakan ( Action) dari kepala madrasah menjalankan program-program nya di antaranya seperti yang di sampaikan oleh ibu Atin Sugiarti, M.Pd:"Saya sebagai kepala madrasah dalam menjalankan program untuk mewujudkan peningkatan eksistensi madrasah yang saya pimpin saya selalu berusaha untuk mewujudkan atau melakukan tindakan-tintakan (Action), diantaranya ; 1) peningkatan dalam bidang sarana prasarana ,dalam hal ini saya berusaha meminta bantuan kepada berbagai pihak terutama dari pemerintah pusat maupun daerah, dalam hal ini Kementrian Agama, juga kepada komite sekolah dan sumbangan yang tidak terikat; 2) Tindakan yang ke dua ini saya melakukan peningkatan kompetensi guru melalui pelatihan-pelatihan guru dalam bentuk KKG/KKMI; 3) Tindakan selanjutnya yaitu meningkatkan kedisiplinan guru yaitu dengan mengadakan apel pagi, mengadakan pembinaan kepada guru yang kurang disiplin,kalau kami tidak sanggup kami melimpahkan ke pikan kantor Kemenag kabupaten; 4) Langkah selanjutnya saya membina hubungan dengan masyarakat sekitar terkhuusus kepada komite sekolah, Stake Holder, dalam rangka mewujudkan kerjasama yang baik; 5) Tindakan selanjutnya adalah melaksanakan programprogram pengembangan diri bagi siswa dinataranya pelaksanaan kegiatan ekstrakurikuler diantaranya kepramukaan, Drun Band, pelatihan seni baca Al-qur'an, pidacil dll; 6) Tindakan selanjutnya yaitu kami berusaha mengikuti perlombaanperlombaan baik di tingkat kecamatan maupun kabupaten.

Demikian juga di ikuti oleh hasil wawancara dengan kepala madrasah lainya, sehingga bisa di devinisikan pada prinsipnya masing-masing kepala madrasah berusaha memaksimalkan pelaksanaan program-program MI tercapainya target-target program yang telah di rencanakan.

\section{Controling}

Dalam Evaluasi pera kepala MI senantiasa mengontrol kegiataan baik secara rutin maupun berkala, hal ini bisa di lihat dari MIS GUPPI No.13 Tasik Malaya, pada dasarnya juga sama yaitu dalam tindakan (Action) dari kepala madrasah menjalankan program-program nya di antaranya seperti yang di sampaikan oleh Nurlelawati, S.Ag, M.Pd. Dalam rangka meningkatkan meningkatkan eksistensi madrasah di Kab. 
Rejang Lebong kami melakukan Evaluasi di antaranya: 1) kami ikut memantau langsung srta ikut serta dalam setiap kegiatan, dengan ini kami bisa mengontrol setiap kegiatan; 2) kami ikut serta dalam setiap kegiatan dengan ini kami bisa menetahui sejauh mana target ketercapaian sehingga semua kegiatan betul-betul terukur tingkat ketercapaiannya. Hasil wawancara tersebut di ikuti wawancara madrasah lainnya, maka pada prinsipnya masing-masing kepala Madrasah senantiasa melakukan pengontrolan dalam kegiatan demi terciptanya konsistensi program.

\section{SIMPULAN}

Strategi yang digunakan dalam meningkatkan eksistensi Kepala Madrasah dalam meningkatkan Eksistensinya adalah dengan strategi POAC, yaitu planning yaitu perencanaan yang strategis untuk meningkatkan eksistensinya di Kabupaten Rejang lebong, organizing yaitu mengorganisasikan program-program secara skala prioritas, actuating yaitu tindakan-tindakan dalam melaksanakan program, dan yang selanjutnya adalah controling yaitu kontrol atau melihat kembali program-program apakah terlaksana dengan baik atau tidak.

\section{DAFTAR PUSTAKA}

Ainin, M. (2007). Metodologi Penelitian Bahasa Arab. Malang: Hilal

Arikunto, S. (2006). Prosedur Penelitian Suatu Pendekatan Praktik. Jakarta: Rineka Cipta

Moleong, L. J. (2008). Metodologi Penelitian Kualitatif. Bandung: PT Remaja Rosda karya

Shaleh, A. R. (2006). Madrasah dan Pendidikan Anak Bangsa, (Cet.3; Jakarta: PT Rajagrafindo persada

Sugiyono, S. (2006). Metode Penelitian Pendidikan: Pendekatan Kuantitatif, Kualitatif dan R\&D. Bandung: Alfab 